\title{
INTERAKSI ANTAR HUKUM DAN PENGARUHNYA TERHADAP PENERAPAN UNDANG-UNDANG PERKAWINAN
}

(Interaction Between Law and Effect on The Application of Marriage Law)

\author{
Ahmad Ubbe \\ Badan Penelitian dan Pengembangan Hukum dan Ham Kementerian Hukum dan HAM \\ Jl. HR. Rasuna Said, Kuningan, Jakarta Selatan \\ Email: ahmadubbe53@gmail.com \\ Tulisan diterima 24-4-2016, Revisi 3-6-2016, Disetujui diterbitkan 22-6-2016
}

\begin{abstract}
This study is juridical-dogmatic. Legal concepts used, is the law of the state, local, and religion; and postulate attached to each family of the law. This research said, the first problem of how interaction between legal system in the country, customs and religions addressed, which occurs when a plurality of law in the implementation of marriage in society? Related to these problems, set objectives and scope of the study, first examine prospect of legal pluralism, towards the establishment of national legal systems in the field of marriage. Both examine the interactions dogma between legal system, especially customs, religions and countries, as a support to realize the marriage in the text and context of the Indonesian nation. The research data is the primary legal materials, secondary and tertiary collected by literature review. The data is processed and analyzed qualitatively-systematically, to unravel the interaction between law, and interpostulate law, as well as the implementation and enforcement of the marriage. Research conclusion, that there has been integration with local laws, religion and state through Act No. 1 of 1974 About Marriage. But in its application no interaction cooperatifinterpostulate related laws and therefore there is a conflict or avoidance of registration of marriage, polygamy and divorce, which is illustrated in the case of marriage, polygamy and divorce, official and unofficial. While the marriage of two people of different religions, carried out by way of conversion, but generally not followed by a customary move. This is a factor not achieving the purpose of marriage. Revealed also that converts to enter into marriage easily occur. On the contrary move in the administration of customary and religious and funeral rites, always gets stiff resistance from those families that originally had a different religion. It is recommended that legal pluralism and interaction between legal system andinterpostulate in it, is solved by reforming marriage laws. Updates marriage law is very urgent, that the law of marriage get a place in the room to the our Indonesian-ness, as a nation-state with a diverse of law.
\end{abstract}

Keywords: Plurality of law and Marraiage Law.

\begin{abstract}
ABSTRAK
Penelitian ini bersifat yuridis-dokmatis. Konsep hukum yang dipakai, ialah hukum negara, lokal dan agama; serta postulat yang melekat pada masing-masing keluarga hukum tersebut. Penelitian ini menjawab, permasalahan pertama bagaimana interaksi antarhukum negara, adat dan agama ditanggapi, mana kala terjadi pluralitas hukum dalam pelaksanaan perkawinan didalam masyarakat? Terkait dengan permasalahan tersebut, ditetapkan tujuan dan ruang lingkup penelitian, pertama meneliti prospek pluralisme hukum, menuju dibentuknya sistem hukum nasional di bidang perkawinan. Kedua meneliti interaksi dokma antarhukum, khususnya adat, agama dan negara, sebagai dukungan mewujudkan perkawinan dalam teks dan konteks negara bangsa Indonesia. Data penelitian ialah bahan hukum primer, sekuder dan tersier yang dikumpulkan dengan cara penelusuran pustaka. Data diolah dan dianalisa secara kualitatif-sistimatis, untuk mengungkap interaksi antarhukum, dan antarpostulat hukum, serta pelaksanaan dan penerapannya terhadap perkawinan. Kesimpulan penelitiaan, bahwa telah terjadi integrasi hukum lokal, agama dan negara melalui UU No 1 Tahun 1974 Tentang Perkawinan. Namun dalam penerapannyatidak terjadi interaksi koorporatif antar postulat hukum yang terkait dan sebab itu terjadi konflik dan atau avoidance antara pendaftaran perkawinan, poligami dan perceraian, yang digambarkan dalam kasus tentang perkawinan, poligami dan perceraian, yang resmi dan tidak resmi. Sementara itu perkawinan dua orang beda agama, dilaksanakan dengan cara pindah agama, tetapi pada umumnya tidak diikuti oleh pindah adat. Hal ini menjadi faktor tidak tercapainyatujuan perkawinan. Diungkap
\end{abstract}


pula bahwa pindah agama untuk melangsungkan perkawinan mudah terjadi. Namun sebaliknya pinda adat dan agama dalam penyelenggaraan dan upacara kematian, selalu mendapat perlawanan dari pihak-pihak keluarga yang semula sudah berbeda agama. Disarankan agar pluralisme hukum dan interaksi antarhukum dan antarpostulat di dalamnya, diselesaikan dengan melakukan pembaruan hukum perkawinan. Pembaruan hukum perkawinan sangat urgen, agar hukum perkawinaan mendapatkan tempatnya dalam ruang ke-Indonesia-an kita, sebagai negara kebangsaan dengan hukum yang beraneka ragam.

Kata Kunci: Pluralitas Hukum dan Undang-undang Perkawinan.

\section{PENDAHULUAN}

Dari sudut pengkajian akademik, konsep pluralisme hukum bukanlah wacana yang sungguh-sungguh baru bagi kehidupan hukum di Indonesia. Terutama bila permasalahan ini ditinjau dari sudut sejarah hukum. Konsep dan permasalahannya,telah dikenal dan digeluti oleh peneliti hukum adat, pada masa sebelum dan saat penjajahan, atau pun awal mula kemerdekaan hingga sekarang.

Indonesia dikenal luas sebagai negara yang dihuni oleh beratus-ratus suku bangsa. Masingmasing suku bangsa mempunyai identitas kebudayaan sendiri-sendiri, setiap suku bangsa mengakui (dan diakui) mempunyai daerah teritorial. Lagi pula setiap suku bangsa mempunyai bahasa, yang berlainan dan biasanya tidak dipahami oleh suku bangsa lainnya (Warnaen, 2002: 310).

Bahkan sebagian diantaranya mempunyai aksara dan kitab hukum sebagai rujukan kebersamaan dan kebudayaan hukum mereka. Di samping itu Indonesia merupakan negara kepulauan,mempunyai wilayah yang paling luas di antara negara kepulauan lainnya di dunia. Sekitar 14.000 pulau tersebar di sepanjang Khatulistiwa. Terbentang di antara $6^{\circ}$ Lintang Utara dan $11^{\circ}$ Lintang Selatan, serta di antara $95^{\circ}$ dan $141^{\circ}$ BujurTimur. Jarak terjauh dari Barat ke Timur adalah $5.110 \mathrm{~km}$. Jarak terjauh dari Utara ke Selatan adalah $1.888 \mathrm{~km}$ (Warnaen, 2002: 310).

Pluralis medan pluralitas (space of plurality) perlu diperhatikan karena alasan, pertama, bahwa pluralitas pada tingkat kesadaran dan sikap belum mampu dijadikan ruang toleransi, dialog dan saling pengertian, serta saling menerima apa adanya, saling melengkapi dan menguatkan. Kedua belum ditemukan cara yang jitu untuk mengelola pluralitas kebudayaan, termasuk pluralitas hukum didalamnya, meskipun dalam hal ini, sarjana ilmu hukum dan kemasyarakatan dengan teliti telah mengkajinya, tetapi mereka jauh dari mendapatkannya.
Berbeda dengan negara-negara di Eropa Barat, dikotomi antara hukum rakyat dan hukum negara diatasi dengan upaya positivisasi hukum masyarakat setempat menjadi hukum nasional. Dengan posistivisasi atau nasionalisasi ataupun formalisasi tersebut, hukum rakyat setempat akan diaku sebagai hukum nasional, yang karena itu diberlakukan dan ditegakkan di seluruh negeri dan oleh badan dan/atau aparatur negara (Wignjosoebroto, 2007: 1).

Upaya nasionalisasi hukum rakyat di negaranegara barat, baik melalui legislasi seperti di Perancis dengan civil law system-nya, atau pun melalui upaya yudisial seperti di Inggris dengan common law systemnya, tidaklah menimbulkan permasalahan interaksi antarhukum. Hal ini disebabkan karena negara-negara barat tersebut, dibangun atas fondasi bangsa yang faktual secara kultural. Sementara di pihak lain, Negara Kesatuan Republik Indonesia (selanjutnya disingkat NKRI) dibangun atas dasar kepentingan politik, yakni kehidupan "bernegara bangsa" di atas kemajemukan sosio-kultural, suku bangsa dan agama.

Seperti dikatakan di atas, interaksi antar hukum dalam penelitian ini, didasarkan pada konsep pluralisme hukum, yang tidak lagi menonjolkan dikotomi antara sistem hukum resmi dan sistem hukum tidak resmi tentang perkawinan. Pluralisme hukum perkawinan tidak lagi cukup digambarkan, melukiskan aneka warna hukum (rechtsbedeling) yang mengatur perkawinan. Namun sekaligus dengan itu adalah soal bagaimana sistem-sistem hukum yang ada tersebut saling berintegrasi satu sama lain, serta bagaimana keberadaan sistem hukum yang beragam itu secara bersama-sama dalam mengatur perkawinan.

Pengelolaan pluralitas hukum, belum begitu berkembang baik. Masalah pluralitas ini merupakan hal yang peka dan menjadi sifat khas negara baru merdeka. Dalam hal ini negara baru merdeka berkeinginan menciptakan suatu tertib politik dan hukum yang efektip. Namun di pihak 


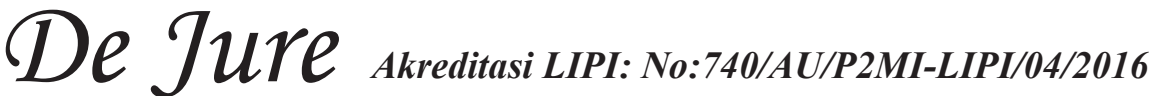

lain terdapat keinginan untuk menyatakan diri, seperti tercerminkan pada identitas premordial suku masing-masing. Keinginan terakhir ini dijejali dan diberati dengan kenyataan ikatan darah, suku, bahasa, agama, tradisi lokal dan sebagainya (Rahardjo, 1976:74).

Kerinduan beridentitas premordial bagi modernisasi hukum, juga diungkapkan oleh Daniel S. Lev yang mengatakan, bahwa cendekiawan hukum Indonesia, pasca revolusi, walaupun merindukan modernisasi hukum, tetapi tetap berada di bawah pesona hukum adat mereka (Daniel S. Lev, 1999:7).

Konsep pluralisme hukum pada awalnya diartikan sebagai keadaan berlakunya lebih dari satu sistem hukum dalam satu wilayah negara, Atau seperti apa yang dimaksudkan Ali Afandi, yaitu berlakunya sistem hukum yang berlain-lainan terhadap golongan penduduk tertentu (Affandi, 1985: 2). Namun di dalam kajian antropologi hukum masa kini, John Griffit, seorang peneliti, mengatakan pluralisme hukum terjadi, apabila di dalam satu wilayah sosial berlaku lebih dari satu tertib hukum (Griffiths, 2005: 69).

Bertolak dari latar belakang pemikiran disebut di atas, penelitian ini terkait dengan konsep pluralisme hukum yang tidak lagi dirancang secara dikotomis antara hukum negara dan adat; hukum lokal, hukum agama dan seterusnya. Namun dengan paradigma baru yang tidak dikotomis, yakni melihat relasi interaktif, kompetitif dan saling mempengaruhi antara tertib hukum yang satu dengan tertib hukum lain dalam suatu wilayah sosial tertentu (Simarmata, 2005: 8).

Pluralitas kebudayaan (termasuk hukum) sering didekati dengan ancangan konflik. Dalam pemikiran konflik ini, lazinnya permasalahan difokuskan pada situasi persaingan antara ego dengan alam pikiran individu; antara loyalitas etnik, agama dan kepercayaan dengan loyalitas nasional (Simarmata, 2005: 8).

Dalam rangkaian kerja teori konflik yang demikian, seringkali diskusi berkutak-katik pada soal hubungan antara orientasi hukum masa lalu, masa kini dan hukum masa depan yang terdapat dalam pikiran dan catatan sejarah hukum kita. Berbeda dengan pendekatan konflik disebut di atas, Koentjaraningrat mengajukan "pendekatan intergaratif" dengan mengatakan, bahwa loyalitas etnik dan loyalitas nasional mendominasi dua bidang kehidupan pribadi dan bidang kehidupan umum, sehingga dengan demikian kedua loyalitas itu lebih sering melengkapi, daripada saling bersaing atau saling terlibat konflik (Koentjaraningrat, 1993: 5).

Dengan demikian penelitian ini dikaitkan dengan permasalahan pokok pertama, apakah hubungan antar suku bangsa dalam negara multietnik, dapatmemperkuatkesatuan bangsanya, tanpa menghilangkan kebudayaan-kebudayaan suku bangsa yang ada. Kedua bagaimana kebudayaan, negara multietnik diperankan untuk mempertahankan kesatuan nasional sebagai satu negara dan bangsa.

Berawal dari permasalahan pokok di atas,penelitian ini menyoal pertama bagaimana interaksi antarhukum negara, adat dan agama ditanggapi, bila terjadi pluralitas hukum dalam pelaksanaan perkawinan di masyarakat?. Pertanyaan di atas, pertama membicarakan prospek pluralisme hukum, menuju terbentuknya sistem hukum nasional di bidang perkawinan. Kedua meneliti intraksi dokma antarhukum, khususnya adat dan hukum negara, sebagai dukungan terwujudnya tujuan perkawinan sesuai dengan UUP.

\section{KERANGKA TEORI}

Kini dan seterusnya untuk NKRI sebagai negara bangsa, telah dilahirkan pandangan guna menjadi arahan pengelolaan pluralitas ke dalam arus "berbeda-beda, tetapi satu"; "bersukusuku, tetapi satu bangsa" dan seterusnya seperti dikemas dalam idiologi nasional dan janji sumpah pemuda serta Garuda lambang negara, yang bertuliskan "bhinneka tunggal ika". Maka semua itu merupakan ruang "ke-Indonesia-an" kita yang perlu diterima dan dipahami dengan penuh tanggung jawab. Hukum nasional sebagai salah satu penghuni ruang ke-Indonesia-an kita, merupakan bagian dari wujud dan isi sistem kebudayaan Indonesia.Oleh sebab itu dibutuhkan rancangan praktis yang tidak melihat komponen tata hukum secara monolistik, tetapi sebagai refleksi pluralime, dimana hukum dilihat sebagai suatu konstruksi kebudayaan dari bangsa yang menjadi tujuan pengaturannya (Marzuki, 1995: 12).

Sejalan dengan nukilan di atas, Ratno Lukito dengan mengutip Masaji Chiba, mengajukan rancangan pemikiran praktis dalam mengkaji 
aspek pluralisme hukum di Indonesia. Ia menyoal pluralisme hukum dengan pertanyaan apakah dengan tatanan hukum yang berbeda-beda, bisa berinteraksi antara satu sama lain, secara harmonis ataupun berkonflik secara baik dalam ikatan kesatuan Indonesia(Lukito, 2008: 12).

Dengan demikian Sistem Hukum Nasional (SHN), komponen dan postulat-postulatnya, tampil sebagai pencerminan multikultural. Dalam hal ini komponen materi hukumnya terdiri dari hukum resmi (hukum negara); hukum non-resmi, seperti adat-istiadat, kebiasaan; dan norma agama dan kaidah-kaidah hukum kolonial yang berlaku positif di Indonesia. Di sisi lain komponen materi hukum, didukung oleh aparatur hukum, kesadaran dan kebudayaan hukum yang dikembangkan menurut fungsi-fungsi yang diharapkan oleh SHN tersebut.

Dari pandangan yang agak berbeda dari pola pikir dijelaskan di atas, tetapi dapat dipakai sebagai kerangka teoritis untuk mengungkap interaksi komponen pluralitas hukum di Indonesia, adalah hubungan segi tiga antara hukum resmi (hukum negara), hukum non-resmi (hukum nonnegara), dan postulat hukum masing-masing yang mendukung dan berhubungan dengan hukum resmi dan tidak resmi tersebut.

Ratno Lukito menjelaskan bahwa hubungan segi tiga antara konstruksi (teradisi) hukum yang membentuk pluralitas hukum Indonesia sebagai berikut:

1) Hukum Resmi, adalah sistem hukum yang diresmikan oleh otoritas negara yang sah. Termasuk juga dalam kategori ini, adalah hukum yang bersumber dari agama, adatistiadat, kebiasaan yang diterima oleh hukum resmi dan diberlakukan sebagai hukum negara.

2) Hukum tidak resmi, adalah hukum yang tidak disahkan oleh otoritas negara yang sah, tetapi didalam praktiknya didukung oleh kelompok masyarakat tertentu, didalam ataupun diluar ikatan negara. Di sini dicatat khusunya meliputi hukum-hukum yang memiliki pengaruh terhadap epektifitas, mengubah atau melemahkan hukum negara itu.

3) Postulat hukum, (resmi dan tidak resmi) tertentu yang berfungsi menjastifikasi dan mengarahkan efektifitas hukum disebut pertama dan kedua (Lukito, 2008 : 12).

Berdasarkan nukilan teoritis di atas, fenomena pluralitas hukum Indonesia secara praktis dapat diungkapkan dengan baik. Meskipun demikian postulat hukum dalam kaitan uraian ini, diartikan sebagai prinsip atau nilai-nilai sosial yang khusus diperankan untuk menjastifikasi pengakuan atau penolakan hukum resmi atau hukum tidak resmi, sebagai komponen hukum nasional kita.

Seperti dikatakan di atas, pemikiran postulat hukum membantu kita memahami aspek pluralisme hukum secara lebih praktis.Dengan demikian dalam diri postulat hukum terdapat penegasan, hukum itu tidak bebas nilai dan tidak pula memiliki karakter seragam, tetepi beragam dan plural.

Ratno Lukito berkesimpulan bahwa postulat hukum merupakan "postulat identitas" yang membuat seseorang bisa mempertahankan identitas hukum sebagai produk kebudayaan. Ia berpendapat melalui identitas hukum ini, orang menentukan memilih dan mentaati hukum resmi atau tidak resmi. Dengan kata lain, menyesuaikan diri dengan perubahan situasi, tetapi dengan tetap mempertahankan identitas diri sendiri sebagai dasar keputusan dan ketaatannya terhadap hukum (Lukito, 2008 : 12).

Melihat konsep hukum dalam penelitian ini, adalah teori, postulat dan asas hukum tentang pluralisme dengan pengembangan budaya hukum nasional, maka penelitian ini berkarakter yudisdokmatis (Wignyosoebroto, 1982 : 230).

Menurut tempatnya, penelitian ini merupakan penelitian perpustakaan. Oleh sebab itu, data penelitian terutama berasal dari bahanbahan hukum primer dan sekunder, khususnya yang berkaitan dengan ruang lingkup penelitian. Data dikumpulkan dengan cara penelusuran bahan pustaka, data diolah secara sistimatis dan kualitatif, gunamenjelaskan interaksi antar hukum resmi (UU Perkawinan), dengan postulat adat dan budaya hukum, sebagai hukum tidak resmi.

Interaksi antarhukum menurut Ade Saptomo, melahirkan empat kemungkinan, yaitu integrasi (intergrate), inkoorporasi (incoorporate), konflik (conflict) dan menghindar (avoidancce). Kemungkinan interaksi, yakni penggabungan sebagian hukum negara dan hukum lokal, sedangkan inkoorporasimerupakan penggabungan 


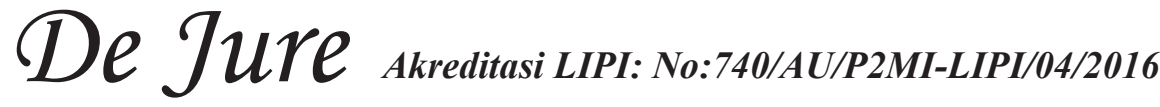

sebagian hukum negara kedalam hukum adat atau sebaliknya. Adapun konflik tidak menyebabkan penggabungan, karena antara hukum negara dan hukum lokal saling bertentangan. Dalam hal ini bahkan terjadi avoidancce, yakni salah satu hukum menghindari keberlakuan hukum yang lain (Saptomo, 2010 : 70).

Interaksi antarhukum tersebut, penting diungkapkan melalui penelitian, guna menjelaskan apa makna teoritis dan filosofis, perkawinan sebagai peristiwa hukum dan kebudayaan. Lagi pula perkawinan tidak cukup diatur oleh hukum negara, tetapi juga oleh hukum adat, yakni aturan yang berlaku dan ditaati bersama oleh masyarakat (Ubbe, 2008 : 45). Bersama dengan itu, penelitian ini bertujuan menyokong upaya-upaya trasformasi hukum positif Indonesia menjadi hukum nasional, sesuai perubahan dan kebutuhan hukum masyarakat(BPHN, 1996 : 50).

UUP sebagai hukum nasional dibutuhkan dalam suatu kehidupan NKRI sebagai negara bangsa. Hukum nasional disebut demikian karena dibentuk atau dibuat oleh suatu organ negara, legislatif ataupun yudisial, dalam bentuk tertulis atau pun tidak tertulis. Hukum nasional pada hakekatnya adalah hukum yang kesahan pembentukan dan pelaksanaannya bersumber dari kekuasaan dan kewibawaan negara (Wignjosoebroto, 2007: 2).

Hukum nasional tentang perkawinan dihadapkan pada fakta sosial kultural yang sangat beraneka ragam. Namun sebagai negara bangsa dibutuhkan adanya hukum nasional yang tunggal tentang perkawinan. Bangsa Indonesia pada galibnya bukan lah suatu bangsa yang berkesatuan keturunan, tradisi yang alami. Namun menyatukan diri dengan ikrar bersatu sebagai bangsa.

\section{PEMBAHASAN}

\section{A. Analisis Interaksi Antar Hukum Tentang Perkawinan}

Secara umum interaksi antarhukum menjadi pembicaraan dalam buku-buku ajaran Hukum Intergentil (Hukum antargolongan) yang kemudian berkembang menjadi dan Hukum Antar Tata Hukum. Dalam studi hukum telah terjadi perkembangan, bahwa Hukum Intergentil bergeser menjadi Hukum Antartempat(Interlokal Recht) yang oleh Sunaryati disebut sebagai Hukum Antaradat (Hartono, 1991 : 64).
Sunaryati Hartono mengajukan soal mengapa hukum anatargolongan akan berubah menjadi hukum antaradat dengan alasan, bahwa di masa lampau luas lingkup (geldings gebied) kaidah hukum adat masih terbatas pada wilayah tertentu. Hal ini disebabkan oleh karena penduduk Indonesia masih statis. Namun sekarang dengan bertambah bebasnya orang Indonesia bergerak dari satu daerah ke lain daerah, maka lingkup kuasa berlakunya hukum adat telah meluas ke seluruh wilayah RI. (Abdurrahman, 2007 : 9).

Selanjutnya Sunaryati Hartono, dengan mengutip disertasi Klein, yang banyak ditolak pada waktu itu, tetapi ternyata benar, bahwa bjidragen tot de studie van het intergentil recht. Hal ini sejalan pula pendapat Van Vollenhoven yang memasukkan peleburan (oplossing)menjadi bagian Hukum Antartempat yang kemudian disebut Hukum Antaradat, yang pada akhirnya Hukum Antaradat akan melebur menjadi Hukum Nasional. Hal ini terjadi mana kalahukum antartempat dan batas hukum antaradat semakin menipis (Abdurrahman, 2007 : 9).

Lebih lanjut interaksi antarhukum atau antarsubsistem dari SHN, dapat digambarkan melalui konsep hukum sebagai sistem. Dijelaskan bahwa sistem hukum terdiri dari materi, budaya, lembaga dan aparatur. Keempat komponen sistem hukum itu, senantiasa saling pengaruhmempengaruhi, sehingga apabila salah satu komponennya tidak atau kurang berfungsi, maka seluruh sistem hukum itu tidak akan berfungsi dengan baik (BPHN, 1996 : 19).

Hukum perkawinan menarik ditelaah dalam teks dan konteks pluralitas hukum, sesuai uraian di atas. Perkawinan adalah wilayah sosial yang dihuni oleh lebih dari satu keluarga hukum. Sistem hukum yang ada di dalam Undang-Undang RI No. 1 Tahun 1974 tentang Perkawinan (UUP), dapat digambarkan sebagai berikut:

a) Hukum negara tentang unifikasi hukum di bidang perkawinan (UUP).

b) Hukum agama tentang sahnya perkawinan (Pasal 2 ayat 1 UUP).

c) Hukum adat tentang harta bersama (Pasal 37 UUP).

d) Hukum eks kolonial, hukum adat, hukum agama yang terkait dengan masa peralihan (Pasal 66 UUP). 
Dari data hukum disebut di atas, dapat digambarkan rezim hukum negara, yakni hukum yang sah karena otoritas negara dengan postulat hukum dan identitas hukumnya sendiri, sedangkan substansi hukum adat dan hukum agama yang disebut dalam Pasal-Pasal di atas, juga menjadi hukum resmi karena terintegrasi (integrate) dalam UUP. Namun penerapan dan penegakannya dicakupi oleh postulat hukum asalnya, dari adat dan agama sebagai sumber materiilnya.

Dalam hal ini hukum adat dan agama, sebagai postulat dan identitas hukum, menjadi dasar jastifikasi pelaksanaan Pasal-Pasal UUP seperti disebut di atas. Namun karena hukum adat dan agama telah menjadi materi muatan UUP, maka rezim hukum adat dan agama telah berganti baju serta mendapat sumber formalnya dari negara. Meskipun demikian postulat hukum masingmasing, adat dan agama, tetap merujukpada kebudayaan dan struktur kaidah-kaidah hukum yang melahirkannya. Oleh sebab itu, permasalahan tentang keberlakuan dan keberfungsiannya, tetap berada pada wilayah asalnya masing-masing. Maka dalam hal demikian, diperlukan adanya pembinaan hukum berikutnya, khususnya tentang postulat dan kebudayaan hukumnya masingmasing.

Dalam penelitian kesadaran hukum masyarakat Peusangan (data tahun 1985), diungkapkan, bahwa nilai-nilai hukum adat mempengaruhi penerapan dan penegakan peraturan UUP. Paradigma yang dijadikan obyek penelitian pada saat itu, adalah ketentuan UUP tentang pencatatan perkawinan, poligami dan perceraian yang dipersulit. Dari penelitian tersebut, diungkapkan berbagai hal sebagaimana diilustrasikan berikut ini:

1) Keharusan pencatatan perkawinan sebagai fungsi yang dikehendaki oleh UUP, melahirkan dikotomi dalam pelaksanaannya (conflict). Dari sini dikenal "perkawian resmi" dan "perkawinan tidak resmi" dengan postulat hukumnya masing-masing. Perkawinan bentuk pertama, merupakan perkawinan yang dilaksanakan dalam hukum adat, hukum Islam dan hukum negara, secara sekaligus. Adapun perkawinan bentuk kedua, karena suatu hal, tidak terjangkau fungsi pencatatan nikah yang dikehendaki oleh hukum negara(avoidance). Perkawinan tidak resmi dikualifikasi sebagai perbuatan melenggar undang-undang, tetapi di pihak postulat hukum adat dan Islam, perbuatan ini ditolir. Kedua bentuk perkawinan ini tetap eksis dalam masyarakat Peusangan Aceh Utara. Pelaksanaan kedua bentuk perkawinan ini saling menghindari satu dengan lainnya, karena pertama hukum negara tentang pencatatan perkawinan hanya berlaku bagi perkawinan normal atau biasa, artinya memenuhi syarat formal yang diminta oleh UUP(intergate). Sebaliknya perkawinan tidak resmi, pada umumnya merupakan perkawinan tidak nomal, atau diluar yang biasa,misalnya "kawin hamil". Hukum adat dan Islam "membolehkan kawin hamil"(Abdurrahman, 1992 : 125). Namun dalam pelaksanaannya terdapat perbedaan dalam pelaksanaannya; di sisi hukum adat, wanita hamil dapat dikawinkan baik dengan laki-laki penyebab kehamilan atau laki-laki lain, sebagai penutup malu; sedangkan di sisi hukum Islam, wanita hamil tersebut, hanya boleh dikawinkan dengan laki-laki penyebeb kehamilan wanita yang bersangkutan.

2) Poligami dipersulit sebagai tujuan yang hendak dicapai oleh UUP. Pencapaian tujuan ini menjadi wilayah bekerjanya konsep pluralisme hukum. Meskipun UUP sebagai hukum negara mewajibkan izin poligami dari isteri yang dikeluarkan melalui penetapan pengadilan. Namun praktik poligami tanpa izin isteri ataupun penetapan pengadilan masih eksis seperti keadaan sebelum berlakunya UUP. Hal ini terjadi, pertama karena postulat hukum adat dan Islam, mentolerir praktik laki-laki dapat mempunyai isteri lebih dari seorang.

3) Perceraian dipersulit sebagai tujuan diundangkannya UUP. Pelaksaan fungsi ini tidak terlaksana dengan baik. Perceraian di luar ketentuan UUP masih eksis, meskipun UUP tersebut mengatur perceraian sebagai kewenangan pengadilan negara. Namun dalam pelaksanaan dan penerapannya, UUP dan aparaturnya, tidak cukup berperan menghilangkan bentuk perceraian di bawah tangan. Dari sini, dilahirkan juga dikotomi, 


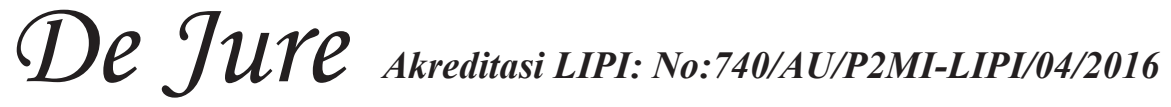

"perceraian resmi" dan "perceraian tidak resmi”. Bentuk perceraian kedua ditolak oleh hukum negara, tetapi dibenarkan oleh hukum adat dan hukum agama. Dari data ini, hukum negara dan postulat-postulatnya, diketahui tidak cukup berwibawa menghentikan kebiasaan perceraian sebagai tindakan sendiri. Sementara perceraian di bawah tangan dibolehkan oleh hukum adat dan hukum Islam (Ubbe, 2008 : 173).

Kedudukan hukum adat dalam UUP menarik dalam pembicaraan pluralisme hukum. Dari pakta hukum yang ada, diketahui bagian tertentu dari hukum perkawinan adat mengalami perubahan. Diketahui dalam UUP asas poligami yang dianut oleh hukum adat dan Islam, diubah menjadi asas monogami. Demikian juga pencatatan pernikahan dan perceraian adalah kewenangan aparatur yang ditunjuk berdasarkan UUP. Bagian lain hukum adat perkawinan yang diangkat dan dijadikan isi UUP, adalah harta benda perkawinan, bila terjadi perceraian diatur menurut hukum masingmasing.

Substansi hukum adat perkawinan, sebagai hukum tidak resmi, yang masih hidup hingga sekarang, adalah rangkaian perbuatan hukum (adat) dalam pelaksanaan perkawinan, yakni peminangan, pernikahan dan respsi perkawinan. Khusus untuk pernikahan di antara dua orang penganut agama Islam, maka perbuatan hukum ijab-kabul dilaksanakan menurut hukum Islam. Perbuatan hukum lainnya, yakni peminangan dan resepsi perkawinan, dilakukan berdasarkan kaidah adat-istiadat. Rentetan perbuatan ini, merupakan perbuatan yang menimbulkan akibat hukum, menurut rezim hukum yang mendasarinya (Ubbe, 2008 : 53).

Bagian dari hukum adat perkawinan yang tersisa dan bertahan hidup ini dilaksanakan sebagai bagian pelengkap dari pelaksanaan Pasal 66 UUP, walaupun hanya sebagai pelengkap tetapi menambah mantap dan membuat pelaksanaan UUP tidak saja sebagai suatu peristiwa hukum, tetapi juga sebagai peristiwa kebudayaan serta bahkan sebagai ibadah menurut agama.

\section{B. Perkawinan Antara Dua Orang Berbeda Agama Menurut Adat Bugis}

Di masa pemerintahan raja Bone ke XXII, La Temmasonge To Appawelling, (1749-1775), dicatat mempunyai 80 putera-puteri dari isteri- isterinya yang berjumlah sangat banyak. Di antara isterinya yang banyak itu, terdapat seorang wanita Belanda dan beragama Keristen. Perkawinan Temmasonge dengan orang Belanda tersebut, digolongkan sebagai pelanggaran adat dan Islam. Oleh sebab itu tidak dicatat dalam silsilah raja-raja Bone. Isteri dan anak-anaknya puntidak menjadi ahli waris kerajaan (Wawancara Andi Mapesissi, Musium Lapawawoi, Watampone, 21 Juli 2004).

Sanksi terhadap pelanggar perkawinan pasangan beda agama, sangat beraneka ragam di antaranya, perkawinan itu tidak melahirkan hubungan kesanak-saudaraan. Dari sebab itu,isteri dan anak pasangan kawin beda agama, tidak saling mewaris harta kekayaan, karena terhalang perbedaan agama.

Prosedur penjatuhan sanksi terhadap pelanggaran perkawinan pasangan berbeda agama melalui beberapa cara. Sebagian melalukan pemutusan hubungan kesanak-saudaraan melalui kenduri yang diakhiri denganmenghayutkan barang milik pelaku pelanggaran larangan kawin antara orang beda agama tersebut.

Sebagian lagi melakukan pemutusan hubungan kesanak-saudaraan hanya dilakukan dengan pernyataan kepada anggota keluarga. Upacara dan pernyataan ini merupakan perbuatan hukum dengan akibat putusnya kekerabatan dan hilangnya hak waris di antara mereka.

Perkawinan pasangan berbeda agama masih terjadi, dari sudut pelakunya, dicatatbaik oleh pasangan wanita suku bugis/Islam dengan lelaki non Bugis/non Islam dan sebaliknya. Berikut ini ada beberapa kasus kawin pasangan berbeda agama yakni:

1. Mempelai Lelaki Bugis/Islam, bernama M. berpendidikan menegah dan berasal dari keluarga berstutus sosial rendah, menikah dengan wanita Minahasa/Keristen, bernama Z. berpendidikan dan berstatus sosial rendah pula. Pada awalnya $\mathrm{M}$ dan $\mathrm{Z}$. bekerja di perusahaan milik paman mempelai lelaki. M melakukan pernikahan tanpa izin dari keluarga, terutama dari pamanya sendiri. Oleh sebab itu $\mathrm{M}$ dinyatakan melanggar larangan agama dan adat keluarga. Pasangan ini dipecat dari perusahaan dan M tidak lagi mempunyai hubungan kekerabatan dengan keluarganya. 
Segala upaya ditempu M untuk mendekatkan diri, isteri dan anak-anak kepada keluarganya, tetapi tidak berhasil. Di pihak keluarga, M dan anaknya bukan siapa-siapa lagi, mereka dianggap telah mati, meskipun masih hidup. Anak-anak, bersama ibu menganut Keristen dan hanya berkerabat dengan keluarga ibunya itu. Sementara M. hidup kadang ke mesjid kadang ke gereja, serta kadang bekerja atau menganggur.

2. Seorang wanita, bernama NW, bangsawan Bugis/Islam, terhormat dan berpendidikan tinggi, berjodoh dengan bangsawan Flores/ Katolik, bernama MB, terhormat dan juga berpendidikan tinggi. Semasi kecil, NW telah menjadi siswi SMP Perater di Makassar. Melanjutkan pendidikan hingga menjadi sarjana di Fakultas Kedokteran Universitas Indonesia. Dalam perjalanan hidupnya, ia berjodoh dengan teman kuliahnya MB, yang kemudian menjadi pejabat dan tokoh yang sangat terpandang dan berpengaruh di daerah asalnya.

Di tengah perjalanan hidup pasangan ini, NW meleburkan diri dan mengikuti agama suaminya. Meskipun hubungan keluarga terputus, NW tidak menyesal dengan agama barunya,yang telah dipelajarinya sejak usia belia.Sementara agama awalnya hanyalah kebetulan, karena sebab kelahiran saja. Meskipun hubungan NW-keluaga terputus, namun NW tidak peduli dan dia telah meleburkan diri di lingkungan adat dan agama suaminya, serta sama sekali lupa pada agama dan tradisi daerah asalnya.

3. Seorang lelaki Bugis/Islam, bernama $\mathrm{AH}$, dosen perguruan tinggi terkemuka di Makassar, berjodo dengan wanita Minahasa/ Keristen, bernama SS, dosen perguruan tinggi di wilayah itu. Ketika pasangan beda agama ini pindah dari Makassar ke Jakarta, karena alasan pendidikan S2, AH diminta menyerahkan foto copy kartu tanda penduduk (KTP) dan kartu keluarga di Rukun Tetangga (RT) setempat. Pada KTP ibu dan dua anaknya tercatat Kristen sebagai agamanya, sedangkan di KTP ayah tercatat Islam sebagai agamanya.
Pada saat AH dirawat di Rumah Sakit, keluaga Bugisnya bergantian membaca Surat Yasin dan diikuti oleh AH. Namun ketika AH koma (sakratul maut) anak, SS dan keluarganya, menyanyikan lagu penghiburan kepada $\mathrm{AH}$, yang tidak lagi sadarkan diri. Tatkala kematiannya datang, AH dimandikan, dikapani dan dikebumikan di pemakaman umum Kristen.

4. Seorang wanita Bugis/Islam, bernama RN, berpendidikan dan berstatus sosial tinggi. $\mathrm{RN}$ dilahirkan oleh seorang ayah dan ibu guru agama Islam. Mendapatkan kekasih, seorang mahasiswa Fakultas Kedokteran, suku Batak/ Katolik, bernama LT. Tatkala pernikahannya berlangsung, LT dan RN menalukkan diri pada syariat Islam dan tradisi Bugis. Namun ketika LT mengucapkan sumpahpada acara wisuda sarjananya, ia melakukannya dengan tradisi Keristen. Setiap Bulan Puasa dan hari raya Islam, LT menyesuaikan diri, bahkan ikut puasa dan salat. Namun pada acara kematian ibunya, LT menyelenggarakan pesta kematian Batak di rumah kediaman LT dan $\mathrm{RN}$, atas dasar alasan LT anak lelaki pertama di keluarganya, maka dia harus ketempatan upacara tersebut.Pada beberapa saat setelah wafatnya, LT dipakaikan busana kematian jas dan celana. Namun beberapa saat setelah itu, jas dan celananya dibuka oleh keluaga $\mathrm{RN}$, kemudian dimandikan dan dikapani sesuai tradisi/syariat Islam. Tujuh hari setelah kematiannya, tahlil dan baca Yasin pun berjalan terus. Anak-anak pasangan LT dan RN menjadi anak soleh dan soleha, rajin mengirim doa kepada ayahandanya secara Islam.

Kedudukan hukum adat perkawinan setelah berlakunya UUP, digambarkan oleh T.O. Ihromidengan mengatakan, bahwa jika sudah diatur, yang menguasainya adalah UUP dan kemudian pelaksanaannya diatur menurut peraturan pelaksanaan, sedangkan mengenai halhal yang sudah tercantum dalam UUP, tetapi belum ada peraturan pelaksanaannya, atau mengenai hal-hal yang sama sekali tidak tercantum dalam Undang-Undang, maka yang menguasainya adalah ketentuan yang ada sebelum 1 Oktober 1975, jadi 


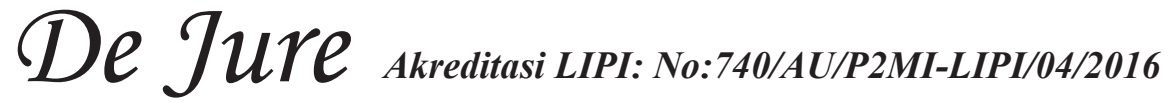

antara lain meliputi hukum adat (Ihromi, 1981: 135).

Adegium yang menggambarkan interaksi antar hukum adat dan agama, terlihat dalam nilai budaya dan adat, seperti yang hidup di Minangkabau, adat bersandi sarak, sarak bersandi Kitabullah. Demikian pula diungkapkan dalam penelitian Franz dan Keebet von Benda Beckmann, bahwa $80 \%$ putusan hakim Pengadilan Negeri di Sumatera Barat berisi hukum adat (Irianto, 2007 : 4-5).

Selanjutnya persoalan hubungan hukum Islam dengan hukum adat di Aceh perlu mendapatkan perhatian. Dilihat dari titik pandang hukum Islam, yang mengenal postulat hukum Al-Adat Muhakkamah, yang berarti adat dapat dijadikan hukum. Konsepsi dan cara kerja ulamaulama Islam, dalam transformasi hukum, bila posisi adat berhadapan dengan hukum Islam, maka hukum Islam mentolerir praktik adat, sepanjang tidak berlawanan dengan ketentuan eksplisit dari Qur'an dan Hadis (Syahrizal, 2004: 1; Muhammad, 1985 : 322).

Di sisi lain, postulat hukum adat melihat hubungannya dengan hukum Islam sebagai hubungan yang saling melengkapi. Di masyarakat hukum Aceh hubungan ini dirujuk pada postulat hukum "hukoom ngong adat, lagee zat ngon sifeuet". Maksud perkataan itu, ialah hukum adat dan hukum Islam satu, tak terpisahkan, seperti satunya sifat dan zat. Hubungan menyatu adat dan agama, dijelaskan lebih lanjut dalam postulat hukum yang mengatakan, "adat bak poteu meureuhom, hukoom bak Syiah Kuala". Maksudnya adat dipegang oleh raja, sedangkan hukum (Islam) dipegang oleh ulama(Ubbe, 1985 : 8; Ubbe, 1988 : 173).Jadi dalam hal ini, hubungan hukum adat sebagai "hukum kerajaan" ditempatkan setara dan dalam ikatan sinergis dengan hukum Islam sebagai "hukum ulama".

\section{KESIMPULAN}

Undang Undang No 1 Tahun 1974 Tentang Perkawinan, sebagai hukum negara telah mengitegrasikan hukum lokal dan hukum agama tentang perkawinan. Pelaksanaan dan penerapan UUP berinteraksi dalam lokal sosial sama, sesuai obyek penelitian yakniparadigma pencatatan perkawinan, monogami, perceraian, perkawinan antara pemeluk agama yang berbeda.
Analisis interaksi antarhukum di bidangbidangpencatatan perkawinan, monogami, perceraian, perkawinan antara pemeluk agama yang berbeda, mengungapkan bahwa hukum lokal dan agama berhasil dintegrasikan dalam UUP, sebagai hukum negara. Namun kemudiantidak terjadi inkoorporasi dalam pelaksanaan dan penerapannya. Hal ini disebabkan masih terjadinyakonflik dikotomis antarpostulat hukum negara dan lokal serta agama tentang pencatatan perkawinan, poligami dan perceraian. Kini dalam peristiwa konkrit masih terjadi avoidance antara pencatatan perkawinan, perceraian dan poligami resmi dan tidak resmi. Hal yang sama terungkap pula bahwa perkawinan antara pemeluk agama yang berbeda, diterapkan dengan pilihan pindah agama. Namun pada umumnya belum diikuti dengan pindah adat, meskipun kemudian menjadi faktor tidak tercapainya tujuan perkawinan, sesuai yang dikehendaki oleh UUP.

\section{SARAN}

Penelitian interaksi antarhukum perlu digiatkan guna menempatkan hukum nasional, dalam hal ini UUP, dalam ruang ke-Indonesiaan kita, agar tercapai tujuan perkawinan dengan baik, sesuai hukum perkawinan dan nilai agama serta budaya bangsa Indonesia.

Perlu upaya perubahan UUP, yang ditunjang oleh penelitian interaksi antarhukum tentang kaidah hukum perkawinan, aturan agama dan norma sosial budaya bagiterwujudnya lembaga perkawinan guna pembangunan keluarga bahagia lahir dan batin. 


\section{DAFTAR KEPUSTAKAAN}

Abdurrahman, Kompilasi Hukum Islam di Indonesia, Jakarta: Akademika Pressindo, 1992.

"Hukum Adat Dalam Perkembangan Pluralisme Hukum di Indonesia”, Seminar Pluralisme Hukum dan Tantangannya Bagi Pembentukan Sistem Hukum Nasional, Jakarta: BPHN, 2007.

Afandi, Ali. Kedudukan dan Pengaruh Hukum Asing Dalam Pembinaan Tata Hukum di Indonesia, Tanpa Tempat. Terbit: Bina Aksara, 1985.

Badan Pembinaan Hukum Nasional, Departemen Kehakiman RI, Pola Pikir dan Kerangka Sistem Hukum Nasional, Serta Rencana Pembangunan Hukum Jangka Panjang, 1995-1996.

Griffiths, John. "Memahami Pluralisme Hukum, Sebuah Deskripsi Konseptual", PluralismeHukum Sebuah Pendekatan Interdisiplin, Jakarta: HuMa,2005.

Hartono, C.F.G. Politik Hukum Menuju Satu Sistem Hukum Nasional, Bandung: Alumni, 1991.

Ihromi, T. O. Adat Perkawinan TorajaSa'dan Dan Tempatnya Dalam Hukum Positip Masa Kini, Yogyakarta: Gadjah Mada University Press, 1981.

Irianto, Sulistyowati. "Pluralisme Hukum Di Indonesia dan Di Berbagai Negara dalam Era Globalisasi", Seminar Pluralisme Hukum dan Tantangannya Bagi Pembentukan Sistem Hukum Nasional, Jakarta: BPHN, 2007.

Koentjaraningrat, Masalah Kesukubangsaan dan Integrasi Nasional, Jakarta: UI Press, 1993.

Lev, Daniel S.. Hukum dan Politik di Indonesia, Kesinambungan dan Perubahan, Jakarta: LP3ES, 1990.

Lukito, Ratno, Hukum Sakral dan Hukum Sekurel, Studi Tentang Konflik dan Resolusi Dalam Sistem Hukum Indonesia. Jakarta: Pustaka Alvabet, 2008.

Marzuki, Laica. Siri' Bagian Kesadaran Hukum Bugis Makassar (Sebuah Telaah Filsafat
Hukum), Ujung Pandang: Hasanuddin Universitas Press, 1995.

Muhammad Syah, Islmail. Pencaharian Suami Isteri di Aceh Ditinjau Dari Sudut UndangUndang Perkawinan Tahun 1974 dan Hukum Islam, Disertasi Doktor, Medan: Universitas Sumatera Utara, 1985.

Rahadjo, Satjipto. "Persoalan-Persoalan Hukum Dalam Masa Transisi”, Dalam Simposium Kesadaran Hukum Masyarakat Dalam Masa Transisi, Bandung: Binacipta. 1975.

Simarmata, Rikardo. "Mencari Karakter Aksional Dalam Pluralisme Hukum", Dalam Pluralisme Hukum Sebuah Pendekatan Interdisiplin, Jakarta: HuMa, 2005.

Syahrizal, Hukum dan Hukum Islam di Indonesia, Refliksi terhadap Beberapa Bentuk Integrasi Hukum dalam Bidang Kewarisan di Aceh. Batuphat-Lhoksumawe, Nanggroe Aceh Darussalam: Yayasan Nadiya, 2004.

Ubbe, Ahmad. Hukum Adat Kesusilaan Malaweng, Kesinambungan dan Perubahannya, Disertasi Doktor, Jakarta: Watmpone, 2008. ."Beberapa Aspek Kesadaran Hukum Masyarakat Peusangan (Study Tentang Pelembagaan UUP), Pusat Latihan Penelitian Ilmu-Ilmu Sosial Universitas Syiah Kuala, Aceh, 1985.

."Beberapa Aspek Kesadaran Hukum Masyarakat Peusangan (Study Tentang Pelembagaan UUP 1974)", Hukum dan Pembangunan, No. 2 Tahun Ke-XVIII, April 1988.

Warnaen, Suwarsih. Stereotip Dalam Masyaraakat Multietnis, Yokyakarta: Matabangsa, 2002.

Wignjosoebroto, Soetandyo, "Hukum dan MetodaMetoda Kajiannya", dalam Himpunan Bahan Penataran Latihan Tenaga Tehnis Penelitian Hukum, Jakarta, BPHN, 1982.

"Pluralisme Hukum Dalam Masyarakat Indonesia", Seminar Pluralisme HukumDanTantangannyaBagiPembentukan Sistem Hukum Nasiona, Jakarta: BPHN, 2007. 